\title{
RESEARCH
}

Open Access

\section{Proteomic analysis of bone marrow-derived mesenchymal stem cell extracellular vesicles from healthy donors: implications for proliferation, angiogenesis, Wnt signaling, and the basement membrane}

Jeffrey D. McBride ${ }^{1,2}$, Luis Rodriguez-Menocal ${ }^{1,2}$, Wellington Guzman ${ }^{1,2}$, Aisha Khan², Ciara Myer ${ }^{3,4}$, Xiaochen Liu', Sanjoy K. Bhattacharya ${ }^{3,4}$ and Evangelos V. Badiavas ${ }^{1,2^{*}}$

\begin{abstract}
Background: Bone marrow-derived mesenchymal stem cells (BM-MSCs) have shown therapeutic potential in various in vitro and in vivo studies in cutaneous wound healing. Furthermore, there are ubiquitous studies highlighting the pro-regenerative effects of BM-MSC extracellular vesicles (BM-MSC EVs). The similarities and differences in BM-MSC EV cargo among potential healthy donors are not well understood. Variation in EV protein cargo is important to understand, as it may be useful in identifying potential therapeutic applications in clinical trials. We hypothesized that the donors would share both important similarities and differences in cargo relating to cell proliferation, angiogenesis, Wnt signaling, and basement membrane formation-processes shown to be critical for effective cutaneous wound healing.

Methods: We harvested BM-MSC EVs from four healthy human donors who underwent strict screening for whole bone marrow donation and further Good Manufacturing Practices-grade cell culture expansion for candidate usage in clinical trials. BM-MSC EV protein cargo was determined via mass spectrometry and Proteome Discoverer software. Corresponding proteomic networks were analyzed via the UniProt Consortium and STRING consortium databases.

Results: More than 3000 proteins were identified in each of the donors, sharing $>600$ proteins among all donors. Despite inter-donor variation in protein identities, there were striking similarities in numbers of proteins per biological functional category. In terms of biologic function, the proteins were most associated with transport of ions and proteins, transcription, and the cell cycle, relating to cell proliferation. The donors shared essential cargo relating to angiogenesis, Wnt signaling, and basement membrane formation-essential processes in modulating cutaneous wound repair.
\end{abstract}

\footnotetext{
* Correspondence: ebadiavas@med.miami.edu

${ }^{1}$ Phillip Frost Department of Dermatology and Cutaneous Surgery, University of Miami Miller School of Medicine, 1600 NW 10th Ave, RBSB 2023A, Miami,

FL 33136, USA

${ }^{2}$ Interdisciplinary Stem Cell Institute, Miami 33136, Florida (FL), USA

Full list of author information is available at the end of the article
}

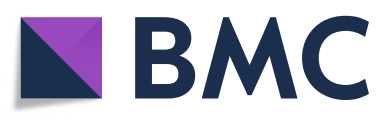

(- The Author(s). 2021 Open Access This article is licensed under a Creative Commons Attribution 4.0 International License, which permits use, sharing, adaptation, distribution and reproduction in any medium or format, as long as you give appropriate credit to the original author(s) and the source, provide a link to the Creative Commons licence, and indicate if changes were made. The images or other third party material in this article are included in the article's Creative Commons licence, unless indicated otherwise in a credit line to the material. If material is not included in the article's Creative Commons licence and your intended use is not permitted by statutory regulation or exceeds the permitted use, you will need to obtain permission directly from the copyright holder. To view a copy of this licence, visit http://creativecommons.org/licenses/by/4.0/. The Creative Commons Public Domain Dedication waiver (http://creativecommons.org/publicdomain/zero/1.0/) applies to the data made available in this article, unless otherwise stated in a credit line to the data. 
Conclusions: Healthy donors of BM-MSC EVs contain important similarities and differences among protein cargo that may play important roles in their pro-regenerative functions. Further studies are needed to correlate proteomic signatures to functional outcomes in cutaneous repair.

Keywords: Stem cells, Extracellular vesicles, Cell cycle, Angiogenesis, Wnt signaling, Basement membrane, Collagen

\section{Background}

The relationship between the skin and other body tissues, such as the bone marrow, is complex and relies on the interaction and exchange of information and signals, including secreted proteins. The bone marrow appears to serve key roles in maintaining skin homeostasis. The relationship of the bone marrow to the skin is intricately connected via its secretome-the totality of proteins produced by the bone marrow that can serve functions in skin tissues. In patients that have dysfunctional bone marrow, the skin may be the first sign of an underlying pathology, through, for example, development of chronic wounds [1], changes in pigmentation, and infection. In subjects with genetic mutations resulting in dermatologic phenotypes, such as forms of epidermolysis bullosa, bone marrow transplants have been shown to be effective in attenuating skin pathology [2]. While bone marrow-derived mesenchymal cells (BM-MSCs) have been shown to be beneficial in a variety of diseases, including wound healing [3-5], but engraftment and survival into other tissues after transplant is very low, the exact mechanisms as to how patients experience benefit from cellular therapy remain to be fully understood. We hypothesized that the secretome of the bone marrow cells contains proteins important in skin structure (ex. basement membrane components) and function that may help explain, in part, the beneficial effects of bone marrow transplants and BM-MSC treatment in patients with cutaneous disease. In this study, using mass spectrometry, we analyzed the proteins in the secretome that co-purified with extracellular vesicles secreted by BM-MSCs from 4 healthy donors.

\section{Methods}

\section{Bone marrow donors}

Collection of primary human donor bone marrow was under the approval of the University of Miami Institutional Review Board (IRB) and in accordance with policies of the Interdisciplinary Stem Cell Institute. All experiments were performed in accordance with relevant guidelines and regulations and complied with the Declaration of Helsinki. Informed consent was obtained for all human subjects, and permission was given by all 4 human subjects to publish results derived from the tissues and cells and, if necessary, to publish any identifying information, including images. The human donors of the bone marrow were a 33-year-old male (donor 1), 33-year-old female (donor 2), 28-year-old female (donor 3), and 28-year-old male (donor 4). As is standard for bone marrow donors at the Interdisciplinary Stem Cell Institute, all 4 donors tested negative for anti-human immunodeficiency virus (HIV)-1/HIV-2, anti-human lymphotrophic virus (HTLV) $\mathrm{I} / \mathrm{II}$, anti-hepatitis $\mathrm{C}$ virus (HCV), HIV-1 nucleic acid test, HCV nucleic acid test, hepatitis B surface antigen (HBsAg), anti-HBc (core antigen) (IgG and IgM), anticytomegalovirus (CMV), West Nile virus (WNV) nucleic acid, T. cruzi ELISA (Chagas disease), rapid plasma regain (RPR) for syphilis, and had no clinical/history/laboratory evidence to suggest Creutzfeldt-Jakob disease. The bone marrow (approximately $80 \mathrm{~mL}$ ) was aspirated from the posterior iliac crests as per standard practice of the University of Miami Bone Marrow (BM) Transplant Programs. The marrow was aspirated into heparinized syringes, and labeled syringes were transported at room temperature to the Good Manufacturing Practices (GMP) facility at the Interdisciplinary Stem Cell Institute at the University of Miami. BM was processed using Lymphocyte Separation Medium (LSM; specific gravity 1.077) to prepare the density-enriched, mononuclear cells (MNCs). Cells were diluted with Plasmalyte A or phosphatebuffered saline (PBS) buffer and layered onto LSM using conical tubes to isolate MNCs following established standardized operating procedures. The MNCs were washed with Plasmalyte A or PBS buffer containing 1\% human serum albumin (HSA). The washed cells were sampled to determine the total number of viable nucleated cells. MSCs were initially cultured in Alpha-MEM media (Corning Cat. No 15-012-CV) supplemented with $2 \mathrm{mM} \mathrm{L-}$ glutamine, 20\% fetal bovine serum (FBS), 100 units $/ \mathrm{ml}$ penicillin, and $100 \mu \mathrm{g} / \mathrm{ml}$ streptomycin. The expansion was performed in T175 $\mathrm{cm}^{2}$ flasks (Corning Cat. No $431466)$ at $37^{\circ} \mathrm{C}$, using a $5 \% \mathrm{CO}_{2}$ humidified incubator. MSCs were detached from the culture vessels using trypsin exposure, passaged, and cryopreserved at passage three prior to use in the following experiments. MSCs were verified in the GMP as viable, $\mathrm{CD} 105^{+}, \mathrm{CD} 45^{-}$cells, sterile, mycoplasma-free, and endotoxin-free. Our previous work with MSCs of this nature revealed expression of HLA-class 1, CD90, CD73, and CD105 while being negative for $\mathrm{CD} 45$, and contained differentiation capacity into different lineages [6, 7].

\section{Isolation of EVs}

Passage three cells were taken from cryopreservation, recovered, and cultured in T75 $\mathrm{cm}^{2}$ flasks (Corning Cat. 
No 3276) until 80\% confluency, at which time the MSCs were washed several times with PBS, switched to serumfree Alpha-MEM media for $24 \mathrm{~h}$ to allow for EV collection into the serum-free media, which was then isolated and processed for downstream isolation using ExoQuick-TC ${ }^{\bullet}$ ULTRA EV Isolation Kit for Tissue Culture Media (Cat \# EQULTRA-20TC-1), according to the manufacturer's instructions. Dot blot was performed to verify extracellular vesicles were isolated without cellular contaminants (Exo-Check Exosome Antibody Arrays, Cat \# EXORAY200A-4, Cat \#EXORAY210A-8) according to the manufacturer's instructions.

\section{Processing of EV samples prior to mass spectrometry analysis}

Lysing the EVs were as follows (all reagents from Sigma, unless otherwise stated). Isolated extracellular vesicles were centrifuged for $10 \mathrm{~min}$ at $2000 \times g$ at $4^{\circ} \mathrm{C}$. Samples were speed vacuumed dry until the sample was dry. Fifty microliters of $20 \mathrm{mM}$ Tris-2\% (sodium dodecyl sulfate) SDS was added. The mixture was heated at $95^{\circ} \mathrm{C}$ for $30 \mathrm{~s}$ and chilled for $30 \mathrm{~s}$; this was cycled for a total of $5 \mathrm{~min}$. Samples were sonicated for $1 \mathrm{~min}$. Proteins were precipitated with cold acetone. Samples were speed vacuumed until dry and resuspended in $100 \mu \mathrm{L}$ ammonium bicarbonate. Eight micrograms of protein was added, centrifuged for $10 \mathrm{~min}$, and speed vacuumed until the sample was dry. Eight microliters of $50 \mathrm{mM}$ ammonium bicarbonate ( $\mathrm{pH} 7.8$ ) was added to the samples. Samples underwent denaturation with $15 \mu \mathrm{L}$ of $10 \mathrm{M}$ urea in 50 $\mathrm{mM}$ ammonium bicarbonate ( $\mathrm{pH}$ 7.8). Samples were reduced using $2 \mu \mathrm{L}$ of 125 dithiothreitol DTT in $50 \mathrm{mM}$ ammonium bicarbonate $(\mathrm{pH}$ 7.8). Samples were incubated for $1 \mathrm{~h}$ at room temperature. Samples underwent alkylation with $5 \mu \mathrm{l}$ of $90 \mathrm{mM}$ iodoacetamide in $50 \mathrm{mM}$ ammonium bicarbonate, $\mathrm{pH}$ (7.8) and incubated in room temperature for $30 \mathrm{~min}$. Samples were quenched with $3.33 \mu \mathrm{L}$ of $125 \mathrm{mM}$ DTT in $50 \mathrm{mM}$ ammonium bicarbonate ( $\mathrm{pH}$ 7.8). Samples were incubated at room temperature for $1 \mathrm{~h}$ in the dark. Ammonium bicarbonate (50 $\mathrm{mM}$ ) was added to dilute urea to 1 molar concentration. Samples were digested with trypsin corresponding to $1: 30 \mathrm{w} / \mathrm{w}$ enzyme to protein and incubated overnight at $37^{\circ}$ for $18 \mathrm{~h}$. Formic acid (50\%) was added to stop trypsin reaction (5:100 v/v formic acid to sample). Samples were desalted using the Pierce C18 Spin Tips (Thermo Scientific). Trifluoroacetic acid (TFA) (2.5\%) was added to the sample to adjust TFA concentration to 0.05\%; pH of less than 4 was verified. C18 Spin Tips were used were placed into a spin adapter and the tip was wetted with $0.1 \%$ TFA in $80 \%$ acetonitrile (ACN) and centrifuged for $1 \mathrm{~min}$. After discarding the flow through, the sample was added to C18 spin tip and centrifuged at $1000 \times g$ for $1 \mathrm{~min}$; this process was repeated until all sample was passed through the C18 Spin Tip. The Spin Tip was then transferred to a fresh microcentrifuge tube. The sample was eluted by adding $20 \mu \mathrm{L}$ of $0.1 \%$ TFA in $80 \% \mathrm{ACN}$ and centrifuge at $1000 \times g$ for 1 min; this step was repeated again to further elute the sample. The sample was speed vacuumed to dry. The samples were reconstituted in $50 \mu \mathrm{L}$ of $2 \%$ acetonitrile in LC-MS grade water with $0.1 \%$ formic acid prior to LC-MS/MS analysis.

\section{High-performance liquid chromatography (HPLC) and mass spectrometry}

The following methods were performed as previously described [8]. In brief, reversed-phase chromatographic separation utilized an Easy-nLC 1000 system (Thermo) with an Acclaim PepMap RSLC $75 \mu \mathrm{m} \times 15 \mathrm{~cm}$, nanoViper column (Thermo). The solvents were LC-MS grade water and acetonitrile with $0.1 \%$ formic acid. Peptides were analyzed using a Q Exactive mass spectrometer (Thermo) with a heated electrospray ionization source (HESI) operating in positive ion mode. Protein identifications from MS/MS data utilized the Proteome Discoverer 2.2 software (Thermo Fisher Scientific) using Sequest HT search engines. The data was searched against the Homo sapiens entries in Uniprot protein sequence database. The search parameters included precursor mass tolerance $10 \mathrm{ppm}$ and $0.02 \mathrm{Da}$ for fragments, 2 missed trypsin cleavages, oxidation (Met) and acetylation (protein $\mathrm{N}$-term) as variable modifications, and carbamidomethylation (Cys) as a static modification. Percolator PSM validation was used with the following parameters: strict false discover rate (FDR) of 0.01 , relaxed FDR of 0.1 , maximum $\Delta \mathrm{Cn}$ of 0.05 , and validation based on q-value. We obtained the high confidence peptides and filtered out the low and medium confidence peptides.

\section{Results}

The four donors each contained more than 3000 unique proteins identified within their EV cargo (Fig. 1A). More than 600 of these proteins were in common among all four donors (Fig. 1A). In terms of biologic function, the proteins among all donors had similar numbers of unique proteins among each functional category (Fig. 1B). The most common functional categories were proteins involved in transport (especially transport of ions and other proteins), followed by transcription, cell cycle, ubiquitin conjugation pathways, cell adhesion, deoxyribonucleic acid (DNA) damage, immunity, lipid metabolism, sensory transduction, host-virus interaction, apoptosis, messenger ribonucleic acid (mRNA) processing, neurogenesis, cilium biogenesis/degradation, protein biosynthesis, endocytosis, ribosome biogenesis, Wnt signaling, DNA replication, inflammatory response, 

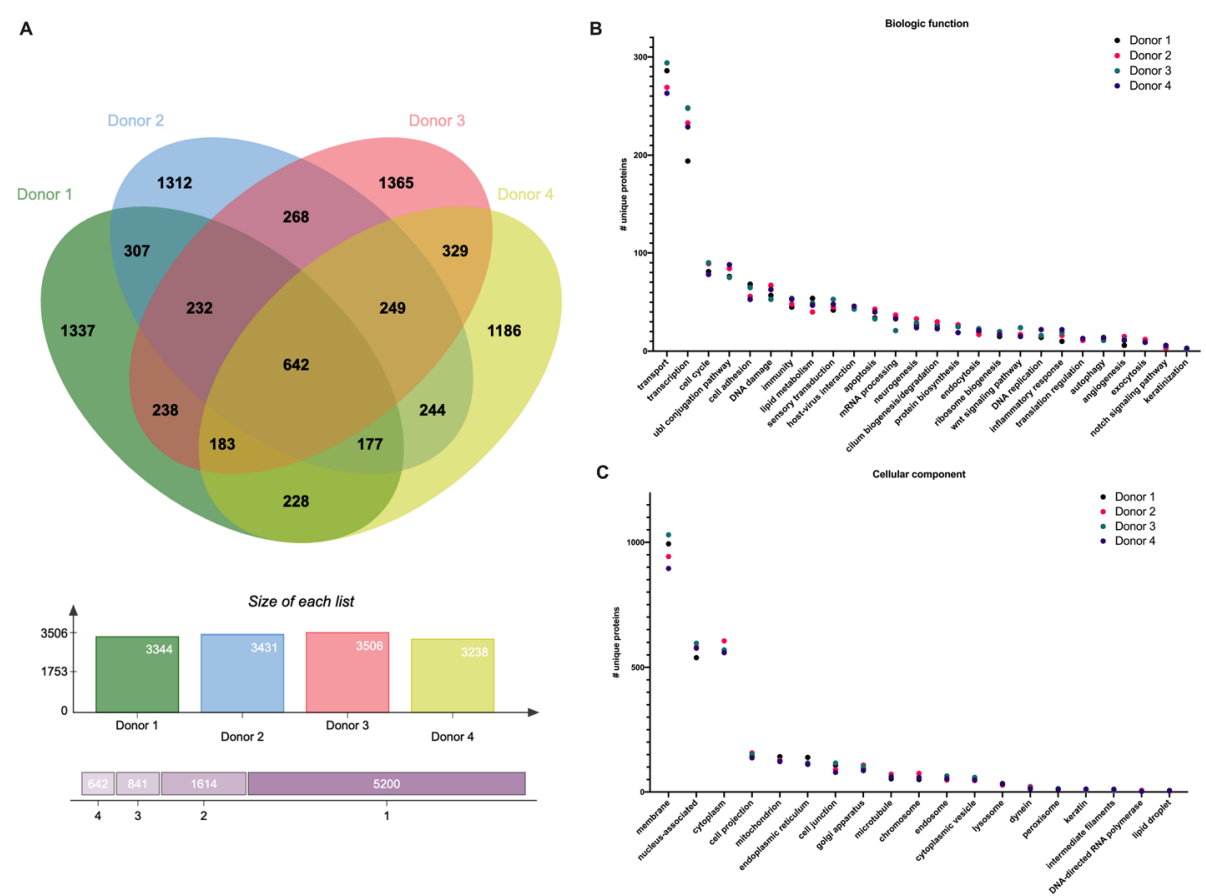

Fig. 1 BM-MSC EVs contain diverse protein cargo relevant to a wide variety of biologic functions. A Venn diagram across all 4 healthy human donors. B Biologic functions and C cellular components of BM-MSC EVs across all 4 donors (\# of unique proteins per category)

translation regulation, autophagy, angiogenesis, exocytosis, notch signaling, and keratinization (Fig. 1B). In terms of the cellular component with which the proteins were associated, the most common were proteins associated with the cell membrane, followed by the nucleus, cytoplasm, cell projections, mitochondrion, endoplasmic reticulum, cell junctions, golgi apparatus, microtubules, chromosomes, endosomes, cytoplasmic vesicles, lysosomes, dynein, peroxisomes, keratin, intermediate filaments, DNA-directed RNA polymerase, and lipid droplets (Fig. 1C).

Using the STRING consortium database, we visualized the structural and functional networks among the common proteins involved in transport (Fig. 2A). Central among the network were calcium transport-related proteins, such as the Voltage-dependent T-type calcium

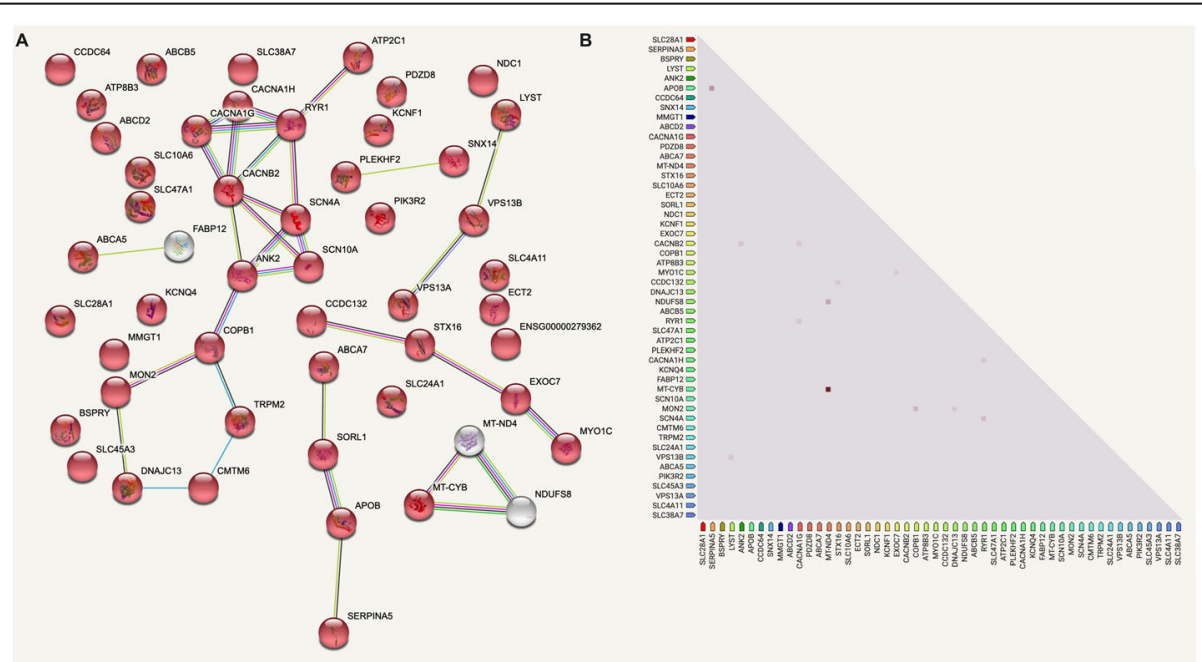

Fig. 2 BM-MSC EVs contain important proteins involved in the transport of biologically active proteins and ions. A Proteomic network involving proteins in all four donors classified as protein or ion transporters. B Coexpression map based on STRING database aggregation of experimental data in which proteins are known to be expressed together 
channel subunits alpha-1G (CACNA1G) and alpha-1H (CACNA1H) (Fig. 2A), which mediate the entry of calcium ions into cells and is involved in cell motility, cell division, and gene expression $[9,10]$. Closely related in this hub was the voltage-dependent L-type calcium channel subunit beta-2 (CACNB2) (Fig. 2A), which increases the peak calcium current across cell membranes [11]. Ryanodine receptor 1 (RYR1), another calcium channel that is also expressed in epidermal keratinocytes and associated with keratinocyte differentiation and epidermal permeability barrier homeostasis [12], was detected in all donor EVs (Fig. 2A). Calcium-transporting ATPase type $2 \mathrm{C}$ member 1 (ATP2C1), a magnesiumdependent enzyme that is critical in calcium homeostasis and keratinocyte adhesion, was functionally connected to the aforementioned proteins (Fig. 2A) [13]. Several sodium-related channels were discovered in EVs. The sodium channel proteins type 4 subunit alpha (SCN4A) and type 10 subunit alpha (SCN10A) were present (Fig. 2A) [14]. Transient receptor potential cation channel subfamily M member 2 (TRPM2), a voltage-independent cation channel mediating both sodium and calcium influx, was detected (Fig. 2A) [15]. The detected transport proteins also included endosomal trafficking-related proteins, such as DnaJ homolog subfamily $\mathrm{C}$ member 13 (DNAJC13) [16, 17] (Fig. 2A), which is involved in membrane trafficking through early endosomes and implicated in recycling epidermal growth factor receptor. Coatomer subunit beta (COPB1) [18, 19] (Fig. 2A) is a cytosolic protein that associates with vesicles from the Golgi apparatus and mediating protein transport from the endoplasmic reticulum. BM-MSC EV cargo contained proteins involved in electron transport that have been shown to be co-expressed together in independent

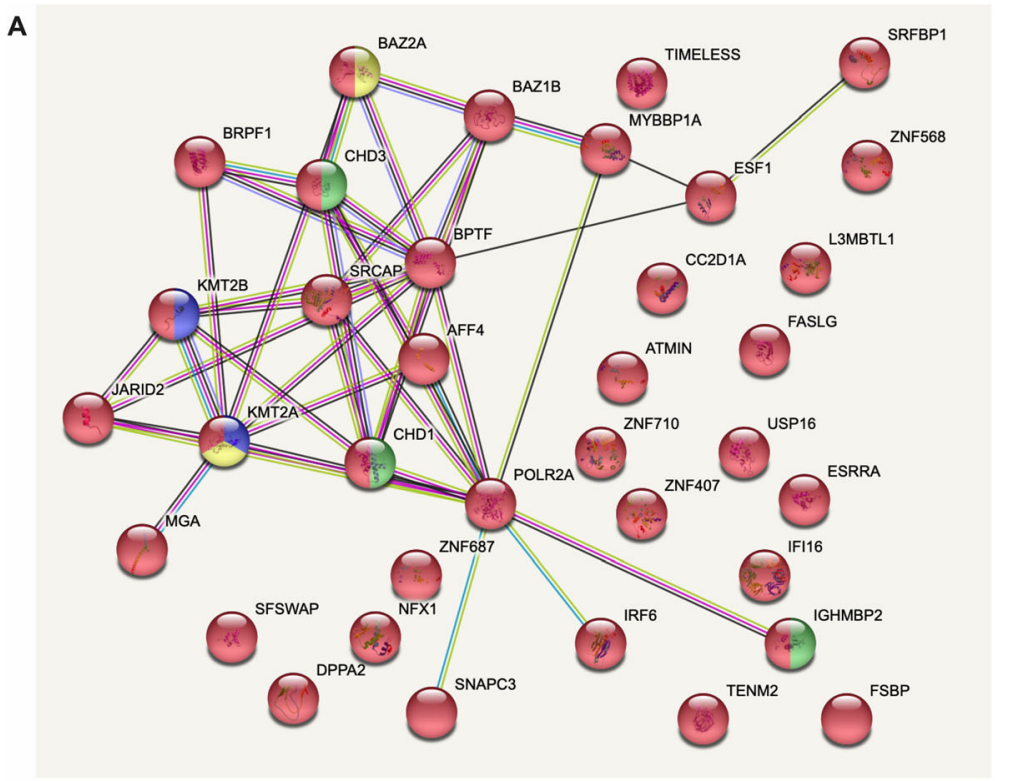

\begin{tabular}{|c|c|c|c|c|}
\hline$\checkmark$ & Biological Process (Gene Ontology) & & & \\
\hline GO-term & description & count in network & strength & false discovery rate \\
\hline GO:0080182 & histone $\mathrm{H} 3-\mathrm{K} 4$ trimethylation & 2 of 15 & 1.86 & 0.0048 \\
\hline GO:0051569 & regulation of histone $\mathrm{H} 3-\mathrm{K} 4$ methylation & 2 of 26 & 1.62 & 0.0112 \\
\hline GO:0045815 & positive regulation of gene expression, epigenetic & 3 of 51 & 1.5 & 0.0016 \\
\hline G0:0048536 & spleen development & 2 of 34 & 1.5 & 0.0173 \\
\hline GO:0032508 & DNA duplex unwinding & 3 of 53 & 1.49 & 0.0017 \\
\hline GO:0031062 & positive regulation of histone methylation & 2 of 36 & 1.48 & 0.0185 \\
\hline GO:0042149 & cellular response to glucose starvation & 2 of 37 & 1.47 & 0.0193 \\
\hline G0:0031060 & regulation of histone methylation & 3 of 58 & 1.45 & 0.0022 \\
\hline GO:0006306 & DNA methylation & 2 of 46 & 1.37 & 0.0283 \\
\hline GO:0045652 & regulation of megakaryocyte differentiation & 3 of 78 & 1.32 & 0.0048 \\
\hline GO:0032922 & circadian regulation of gene expression & 2 of 55 & 1.3 & 0.0386 \\
\hline GO:0016575 & histone deacetylation & 2 of 57 & 1.28 & 0.0410 \\
\hline G0:0072332 & intrinsic apoptotic signaling pathway by p 53 class mediator & 2 of 58 & 1.27 & 0.0420 \\
\hline GO:0006338 & chromatin remodeling & 5 of 156 & 1.24 & 0.00015 \\
\hline G0:0016573 & histone acetylation & 3 of 96 & 1.23 & 0.0082 \\
\hline G0:0016569 & covalent chromatin modification & 9 of 357 & 1.14 & $2.70 \mathrm{e}-07$ \\
\hline G0:0040029 & regulation of gene expression, epigenetic & 6 of 251 & 1.11 & $9.41 \mathrm{e}-05$ \\
\hline G0:0016570 & histone modification & 8 of 347 & 1.1 & $3.33 \mathrm{e}-06$ \\
\hline G0:0007623 & circadian rhythm & 3 of 137 & 1.08 & 0.0181 \\
\hline G0:0006325 & chromatin organization & 12 of 683 & 0.98 & $3.99 \mathrm{e}-08$ \\
\hline GO:0045637 & myeloid cell differentiation & 4 of 249 & 0.94 & 0.0110 \\
\hline G0:0018205 & peptidy-lysine modification & 4 of 250 & 0.94 & 0.0110 \\
\hline GO:0006351 & transcription, DNA-templated & 36 of 2569 & 0.88 & $2.06 \mathrm{e}-29$ \\
\hline
\end{tabular}

Fig. 3 BM-MSC EVs contain cargo important for transcriptional regulation. A Proteomic network involving proteins in all four donors classified as transcriptional regulators. B List of gene ontology identifiers and corresponding color key as indicated (blue = histone H3-K4 trimethylation; green = DNA duplex unwinding; yellow = DNA methylation; red = transcription, DNA-templated) 
experiments of human cells (Fig. 2B) (STRING database analytics). NADH-ubiquinone oxidoreductase chain 4 (MT-ND4) [20], a core subunit of the mitochondrial membrane respiratory chain $\mathrm{NADH}$ dehydrogenase, which plays a critical role in the electron transport chain, was co-expressed with cytochrome b (MT-CYB) [21] (Fig. 2B), which is a component of the ubiquinolcytochrome c reductase complex, also a critical component of the respiratory chain, ultimately contributing to the synthesis of ATP needed for cellular processes. Overall, the donors all shared BM-MSC EV cargo proteins essential to ion, protein, and electron transport.

All donor BM-MSC EV cargo contained important transcriptional regulators. DNA-directed RNA polymerase II subunit RPB1 (POLR2A) [22] was central in the network hub (Fig. 3A). POLR2A is the largest component of RNA polymerase II and catalyzes the transcription of DNA into RNA. AF4/FMR2 family member 4 is a component of the super elongation complex (SEC), which increases the catalytic rate of RNA polymerase II transcription (Fig. 3A) [23]. Epigenetic modulators, such as histone-lysine $\mathrm{N}$-methyltransferases $2 \mathrm{~A}$ and $2 \mathrm{~B}$ (KMT2A and KMT2B) (Fig. 3A) were present in all donor EVs [24]. Also present were chromodomainhelicase-DNA-binding proteins 1 and 3 (CHD1 and CHD3) (Fig. 3A) [25]. CHD1 is an ATP-dependent chromatin-remodeling protein associated with the histone acetylation (HAT) complex regulating RNA polymerase transcription; $\mathrm{CHD} 3$ is a component of the histone deacetylase NuRD complex involved in epigenetic regulation. The helicase, SRCAP, belongs to the SNF2/RAD54 helicase family and mediates ATP-dependent histone modification [26] (Fig. 3A). Jumonji (JARID2) (Fig. 3A) is a regulator of histone methyltransferase by promoting recruitment of histone methyltransferase complexes to their target genes [27]. Bromodomain adjacent to zinc finger domain proteins $2 \mathrm{~A}$ and $1 \mathrm{~B}$ (BAZ2A and BAZ1B) (Fig. $3 A)$ were detected. BAZ2A is an essential component of the nucleolar remodeling complex (NoRC) [28]. BAZ1B is an atypical tyrosine-protein kinase that plays a central role in chromatin remodeling as a component of the WICH complex, which mobilizes nucleosomes and reconfigures chromatin [29]. The enriched functions of the proteins detected in all donors were concentrated in histone $\mathrm{H} 3-\mathrm{K} 4$ trimethylation, epigenetic gene regulation, DNA duplex unwinding, and DNA methylation among others (Fig. 3B).

There were 19 cell cycle-related proteins that were detected in all four donors (Fig. 4A). Most of these proteins were associated with functions in the nucleus (Fig. 4B). MCM7 (Fig. 4C) is a DNA replication licensing factor which is a replicative helicase essential for DNA replication [30]. Timeless (Fig. 4C) plays an important role in DNA replication via maintenance of replication fork and genome stability [31, 32]. Protein DBF4 (Fig.
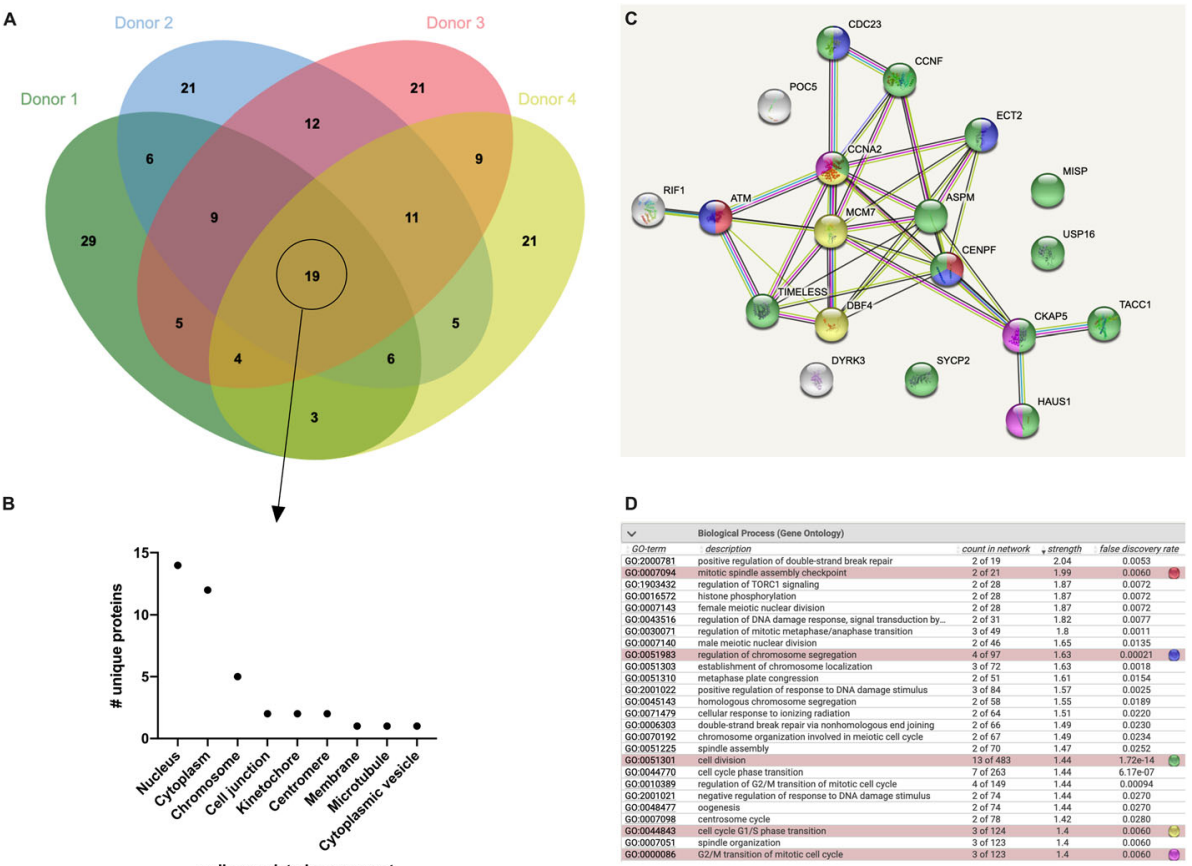

Fig. 4 BM-MSC EVs contain cell cycle-related proteins. A Venn diagram of cell cycle-related proteins across donors. B Cell-associated components of the cell cycle-related proteins. C Proteomic network of cell cycle-related proteins. D List of gene ontology identifiers and corresponding color key as indicated (red = mitotic spindle assembly checkpoint; blue = regulation of chromosome segregation; green = cell division; yellow = cell cycle G1/S phase transition; purple $=$ G2/M transition of mitotic cell cycle) 
4C) plays a central role in DNA replication and cell proliferation. Serine-protein kinase ATM (Fig. 4C) activates checkpoint signaling upon DNA damage [33, 34]. RIF1 (Fig. 4C) is a telomere-associated protein that plays a role in double-strand DNA breaks and promotes nonhomologous end joining-mediated repair [35-37]. Specific cyclins were conserved among the donors' BMMSC EVs. Cyclin-A2 (CCNA2) (Fig. 4C) controls G1/S and $\mathrm{G} 2 / \mathrm{M}$ transition phases in the cell cycle and complexes with cyclin-dependent protein kinases CDK1 and CDK2 [38]. Cyclin-F (CCNF) (Fig. 4C) is a substrate recognition component of the SKP1-CUL-F-box protein E3 ubiquitin-protein ligase complex that mediates proteasomal degradation to inhibit centrosome duplication. Cell division cycle protein 23 homolog (CDC23) (Fig. 4C) is a component of the anaphase promoting complex/cyclosome $(\mathrm{APC} / \mathrm{C})$, which is a cell cycle-regulated E3 ubiquitin ligase that controls cell cycle progression [39]. Centromere protein F (CENPF) is required for kinetochore functions and segregation of chromosomes in mitosis [40]. Abnormal spindle-like microcephalyassociated protein (ASPM) (Fig. 4C) is involved in the regulation of the mitotic spindle [41]. ECT2 (Fig. 4C) is a guanine nucleotide exchange factor that acts on Rho family members and plays roles in signal transduction and cytokinesis [42]. Cytoskeleton-associated protein 5 (CKAP5) (Fig. 4C) binds to microtubules and regulates the organization of microtubules [43].

We hypothesized that BM-MSC EVs would contain angiogenesis-related cargo. Donor 1 and donor 2 shared three angiogenesis-related proteins in common: Neuropilin-1 (NRP1) [44-50], tumor necrosis factor alpha-induced protein 2 (TNFAIP2) [51], and Sushi repeat-containing protein (SRPX2) [52] (Fig. 5A), which have all been demonstrated to be modulators of angiogenesis. Donors 3 and 4 shared three angiogenesisrelated proteins in common (Fig. 5A): NOTCH1 functions as a receptor for membrane-bound ligands Jagged1, Jagged2, and Delta1 to regulate cell-fate and modulate angiogenesis [53-55]; programmed cell death protein 10 (PDCD10) promotes cell proliferation and modulates apoptosis to regulated angiogenesis [56]; PARVA plays a role in sprouting angiogenesis and is required for normal adhesion of vascular smooth muscle cells during blood vessel development [57]. Donors 1 and 4 both contained fibronectin 1 (FN1) (Fig. 5A), which has been implicated in the modulation of angiogenesis [58]. Donors 2, 3, and 4 contained three proteins in common (Fig. 5A): disabled homolog 2-interacting protein (DAB2IP) is a scaffold protein that regulates cell migration and angiogenesis [59]; focal adhesion kinase (PTK2) is a tyrosine kinase that regulates cell migration, adhesion, and endothelial cell spreading [60]; endoribonuclease $\mathrm{ZC} 3 \mathrm{H} 12 \mathrm{~A}$ is involved in mRNA decay and
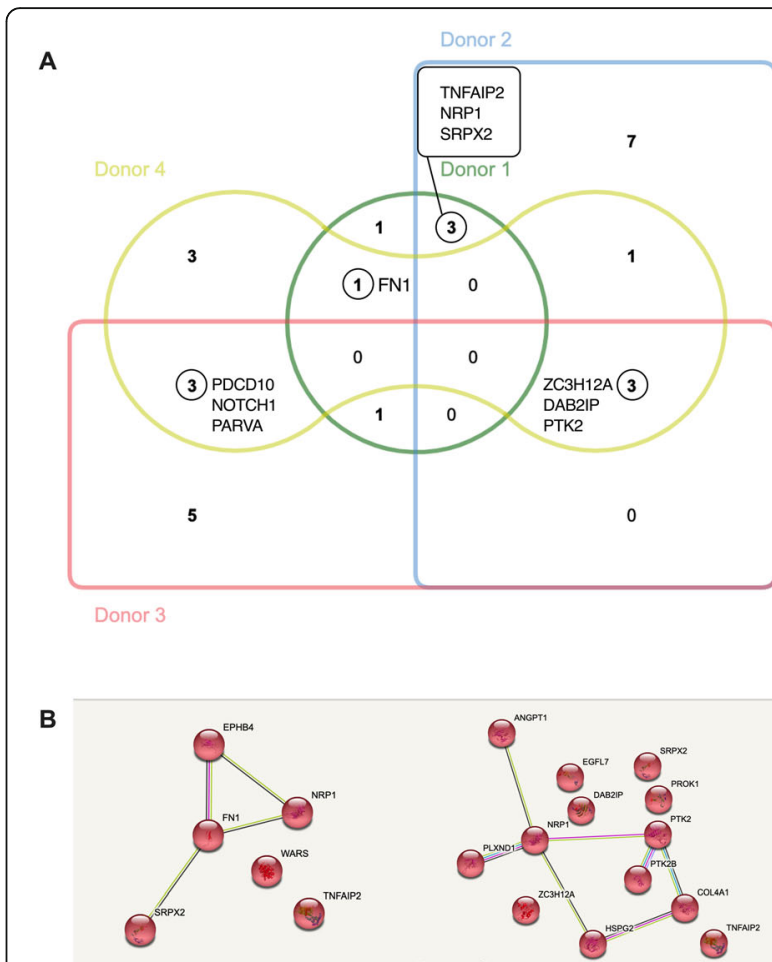

Donor 1
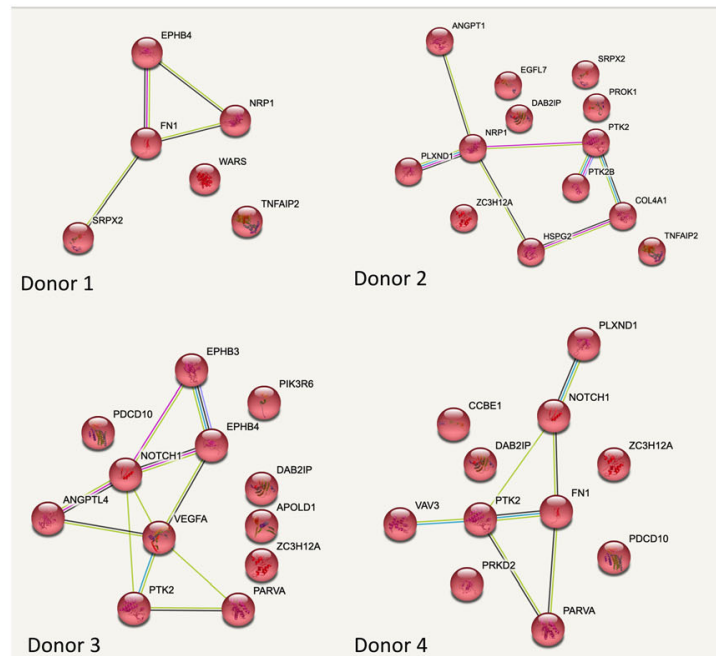

Fig. 5 BM-MSC EVs contain angiogenesis-related cargo. A Venn diagram of angiogenesis-related proteins across donors. B Individual proteomic network maps of angiogenesis-related proteins

across donors

regulates many biologic processes, including angiogenesis [61]. Overall, donors showed wide variability in angiogenesis-related proteins, with some conservation of proteins among selected donors.

Wnt signaling activity has been demonstrated to be important in cutaneous wound healing. We hypothesized that BM-MSC EVs would contain Wnt signaling modulators. All donors' BM-MSC EVs contained the tumor adenomatous polyposis coli (APC) protein (Fig. 6A), which promotes rapid degradation of beta-catenin and consequently regulates Wnt signaling activity [62]. Secreted frizzled-related proteins 1 and 5 (SFRP1 and SFRP5) (Fig. 6A) were also present in all donor BM-MSC EVs. SFRPs function as modulators of Wnt signaling via direct interactions with Wnt ligands in the extracellular environment [63]. Depending on the type of Wnt ligands they bind, 


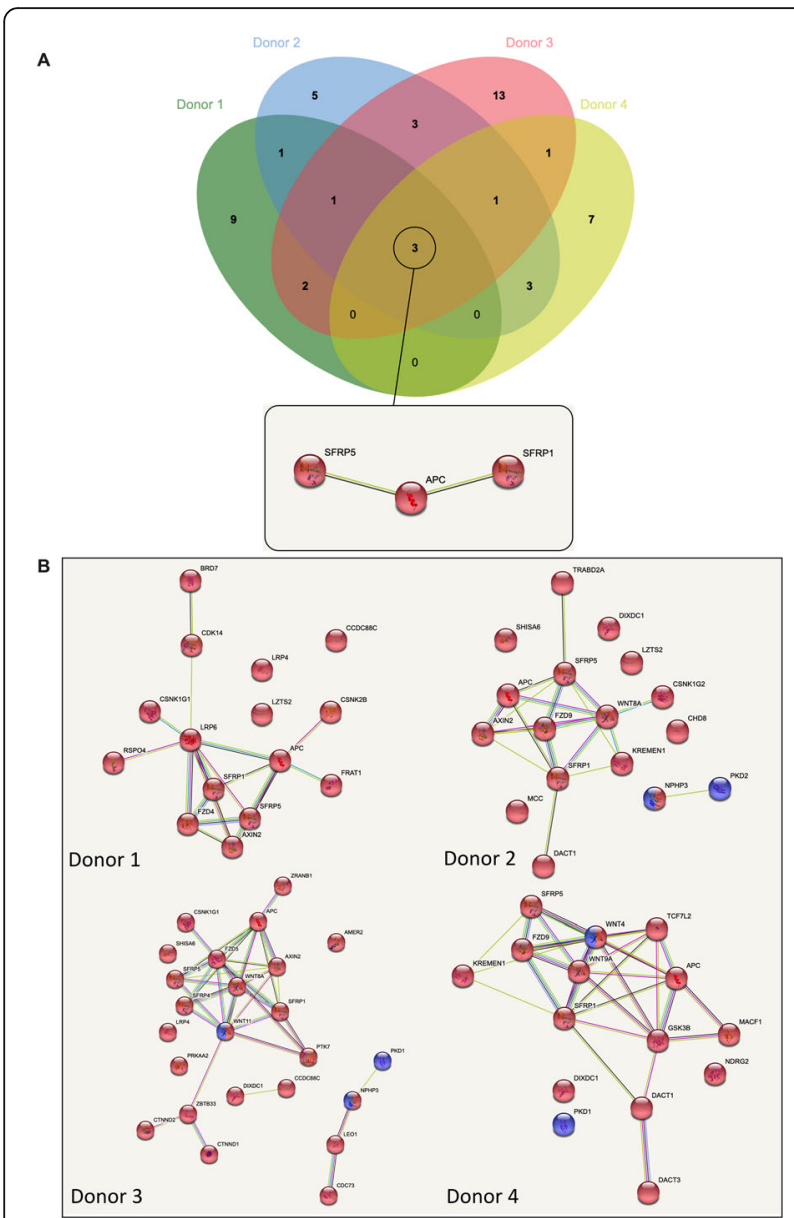

Fig. 6 BM-MSC EVs contain Wht signaling-related proteins. A Venn diagram of Wnt signaling-related proteins across donors. B Individual proteomic network maps of Wnt signaling-related proteins across donors

SFRPs can induce or inhibit canonical Wnt signaling, which may have differing temporal effects on processes such as angiogenesis and fibrosis during cutaneous wound healing $[64,65]$. Various Wnt ligands were expressed in some, but not all, donors. For example, donors 2 and 3 EVs contained WNT8A, while donor 3 contained WNT11 and donor 4 contained WNT4 and WNT9A (Fig. 6B). We found that Wnt receptors were present in BM-MSC EVs. Frizzled (Fz) receptors were found in all donors (Fig. 6B). Low-density lipoprotein receptor-related protein 6 (LRP6) was present in donor $1 \mathrm{EVs}$, while LRP4 was present in donors 1 and 3 (Fig. 6B). AXIN2, present in donors 1, 2, and 3 (Fig. 6B), is a component of Wnt signaling that is involved in beta-catenin degradation [66]. Overall, the BMMSC EVs exhibit both conserved cargo and significant variation that may alter the balance of Wnt signaling.

Given our previous findings, we hypothesized that BM-MSC EVs would contain important basement membrane proteins. All donors' EVs contained multiple

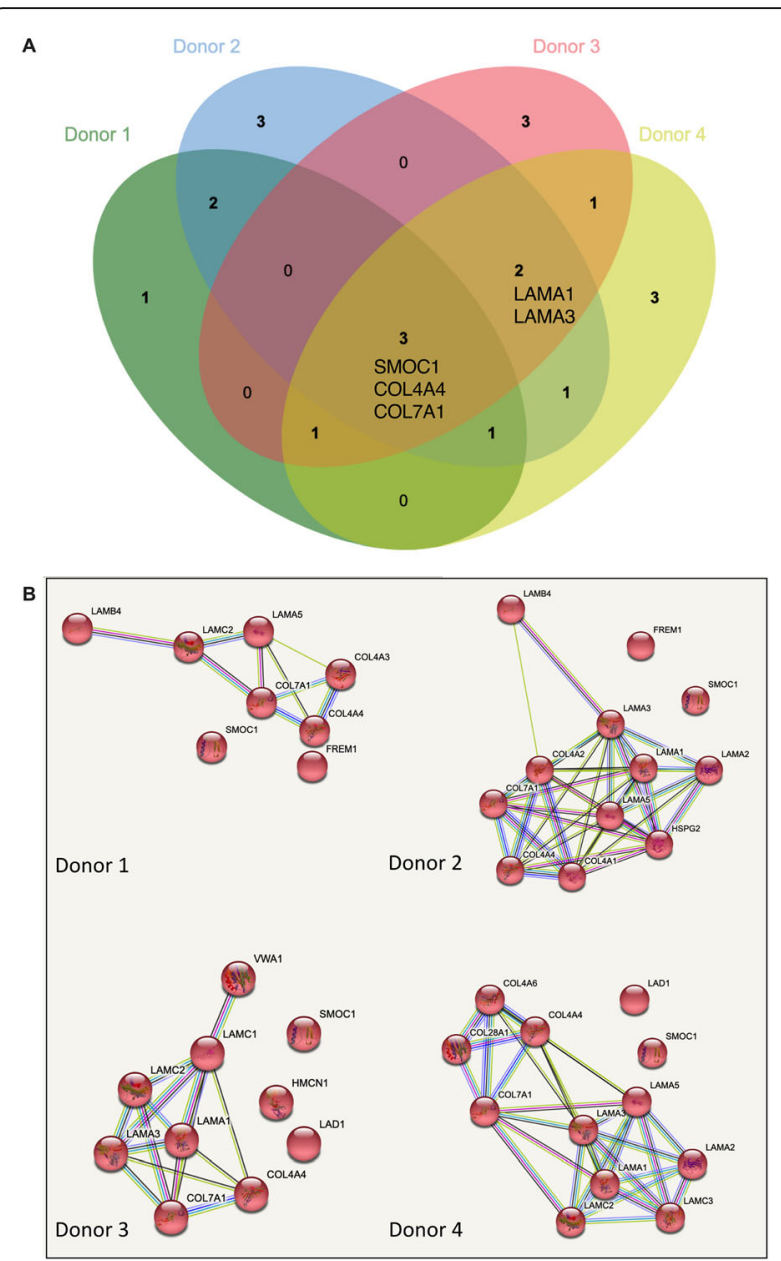

Fig. 7 BM-MSC EVs contain basement membrane proteins. A Venn diagram of basement membrane-related proteins across donors. B Individual proteomic network maps of basement membrane-related proteins across donors

subunits of collagen IV and VII (Fig. 7A, B) [67-69], which are critical in the formation of the skin basement membrane. Donors 2, 3, and 4 contained laminin subunits A1 and A3 (LAMA1 and LAMA3) (Fig. 7A, B), which are crucial in the formation of the basement membrane. Thus, BM-MSC EVs could carry cargo proteins to healing wounds in both damaged skin and in patients with genetic deficiencies.

\section{Discussion}

Our study finds that healthy donors of BM-MSC EVs contain important similarities and differences that should be considered in the development of EVs as therapeutics. BM-MSC EVs carry functional cargo important for a wide variety of biologic processes, including transportation of proteins and ions, transcription, cell cycle, and epigenetic processes, but this list is not exhaustive. With relevance to cutaneous wound healing, BM-MSC 
EVs could play a key role in the promotion of repair and regeneration via its modulation of cell proliferation and angiogenesis and critical signaling pathways, such as Wnt signaling. Furthermore, replenishment of basement membrane proteins is critical to repair and regeneration. An important future avenue of investigation would involve comparing BM-MSC EVs from healthy donors and patients with various diseases (such as chronic wound healing or diabetes); however, we recognize the ethical challenges in obtaining such bone marrow samples in patients at risk for potential complications related to invasive procedures. Additionally, it would be important for screening to understand if there are key, circulating biomarkers in the blood that could predict the relevant cargo that might be contained in a donor's BM-MSC EVs, before isolating the bone marrow. Ideally, some of the key protein cargo from the BM-MSCs identified as useful in the promotion of cutaneous regeneration would be available for detection in the circulation, allowing for a more optimal screening strategy. One limitation of our study is that we only assessed four healthy donors; further studies on a larger number of donors, across different age groups, in independent institutions are needed to help validate cargo signatures in BM-MSC EVs. Furthermore, efforts to correlate proteomic (and genomic) signatures to functional outcomes (in in vitro potency assays and clinical trials) are warranted. Given the importance of stem cells in the development of therapeutics, BM-MSC EVs may play an important role in translational therapeutic development in cutaneous wound repair and regeneration.

\section{Conclusion}

BM-MSCs contain important protein cargo that makes them significant candidates for endogenous contributors and therapeutic candidates for cutaneous wound repair and regeneration. Donor screening for clinical trials is warranted for ultimate application to examine the effects of BM-MSCs on recipient wound healing in a variety of disease conditions.

\footnotetext{
Abbreviations

ASPM: Abnormal spindle-like microcephaly-associated protein; ANC: Acetonitrile; APC: Adenomatous polyposis coli; APC/C: Anaphase promoting complex/cyclosome; BM-MSCs: Bone marrow mesenchymal stem cells; BAZ2A and BAZ1B: Bromodomain adjacent to zinc finger domain proteins $2 \mathrm{~A}$ and $1 \mathrm{~B}$; ATP2C1: Calcium-transporting ATPase type $2 \mathrm{C}$ member 1; CENPF: Centromere protein F; CHD1 and CHD3: Chromodomain-helicaseDNA-binding proteins 1 and 3; CMV: Cytomegalovirus; COPB1: Coatomer subunit beta; CCNA2: Cyclin-A2; CCNF: Cyclin-F; MT-CYB: Cytochrome b; CKAP5: Cytoskeleton-associated protein 5; DAB2IP: Disabled homolog 2 interacting protein; DTT: Dithiothreitol; DNA: Deoxyribonucleic acid; POLR2A: DNA-directed RNA polymerase II subunit RPB1; DNAJC13: DnaJ homolog subfamily C member 13; EVs: Extracellular vesicles; FDR: False discover rate; FN1: Fibronectin 1; GMP: Good Manufacturing Practices; HBc: Hepatitis B core antigen; HBsAg: Hepatitis B surface antigen; HCV: Hepatitis C virus; HESI: Heated electrospray ionization source; HAT: Histone acetylation; KMT2A and KMT2B: Histone-lysine N-
}

methyltransferases 2A and 2B; HIV: Human immunodeficiency virus; HPLC: High-performance liquid chromatography; HSA: Human serum albumin; HTLV: Human T-lymphotrophic virus; JARID2: Jumonji; LAMA1 and LAMA3: Laminin subunits A1 and A3; LC-MS: Liquid chromatography/mass spectrometry; LSM: Lymphocyte separation media; MNCs: Mononuclear cells; mRNA: Messenger ribonucleic acid; MT-ND4: NADH-ubiquinone oxidoreductase chain 4; NRP1: Neuropilin-1; NoRC: Nucleolar remodeling complex; PBS: Phosphate-buffered saline; PDCD10: Programmed cell death protein 10; PTK2: Focal adhesion kinase; RPR: Rapid plasma reagin; RYR1: Ryanodine receptor 1; SDS: Sodium dodecyl sulfate; SFRP1 and SFRP5: Secreted frizzled-related proteins 1 and 5; SCN4A: Sodium channel proteins type 4 subunit alpha; SRPX2: Sushi repeat-containing protein; TNFA IP2: Tumor necrosis factor alpha-induced protein 2; TRPM2: Transient receptor potential cation channel subfamily $\mathrm{M}$ member 2; CACNB2: Voltagedependent L-type calcium channel subunit beta-2; CACNA1G: Voltagedependent T-type calcium channel subunits alpha-1G; Wnt: Wingless-related integration site; WNV: West Nile virus

\section{Acknowledgements \\ We would like to thank The Dermatology Foundation for their support and funding. \\ This work was also supported by EY14801, which is Dr. Vittorio Porciatti's core grant that subsidizes mass spectrometry maintenance.}

\section{Authors' contributions}

$J M$ and EB conceived of the project. JM wrote the manuscript and designed the figures. JM, LRM, WG, and CM performed experiments. AK provided conceptual input, design, and donor sources. $\mathrm{XL}, \mathrm{CM}$, and SB provided help to $\mathrm{JM}$ in data analysis, writing, and figure design. The authors read and approved the final manuscript.

Funding

This work was funded by the Dermatology Foundation Grant to JM.

\section{Availability of data and materials}

JM, LRM, and EB will store raw data and make available upon request.

\section{Declarations}

Ethics approval and consent to participate

Collection of primary human donor bone marrow was under the approval of the University of Miami Institutional Review Board (IRB) and in accordance with policies of the Interdisciplinary Stem Cell Institute. All experiments were performed in accordance with relevant guidelines and regulations and complied with the Declaration of Helsinki. Informed consent was obtained for all human subjects.

\section{Consent for publication}

Permission was given by all 4 human subjects to publish results derived from the tissues and cells and, if necessary, to publish any identifying information, including images.

\section{Competing interests}

$J M, L R M$, and EB have consulted for Aegle Therapeutics. WG, CM, AK, XL, and SB have no competing interests to declare.

\section{Author details}

${ }^{1}$ Phillip Frost Department of Dermatology and Cutaneous Surgery, University of Miami Miller School of Medicine, 1600 NW 10th Ave, RBSB 2023A, Miami, FL 33136, USA. ${ }^{2}$ Interdisciplinary Stem Cell Institute, Miami 33136, Florida (FL), USA. ${ }^{3}$ Bascom Palmer Eye Institute, Miami 33136, Florida (FL), USA. ${ }^{4}$ Miami Integrative Metabolomics Research Center, Miami 33136, Florida (FL), USA.

${ }^{5}$ Katz Family Drug Discovery Center, Miami, FL 33136, USA.

Received: 29 March 2021 Accepted: 19 May 2021

Published online: 05 June 2021

\section{References}

1. Badiavas EV, Ford D, Liu P, Kouttab N, Morgan J, Richards A, et al. Long-term bone marrow culture and its clinical potential in chronic wound healing. Wound Repair Regen. 2007;15(6):856-65. 
2. Wagner JE, Ishida-Yamamoto A, McGrath JA, Hordinsky M, Keene DR, Woodley DT, et al. Bone marrow transplantation for recessive dystrophic epidermolysis bullosa. N Engl J Med. 2010;363(7):629-39. https://doi.org/10.1 056/NEJMoa0910501.

3. Isakson M, de Blacam C, Whelan D, McArdle A, Clover AJ. Mesenchymal stem cells and cutaneous wound healing: current evidence and future potential. Stem Cells Int. 2015;2015:831095.

4. Badiavas EV, Falanga V. Treatment of chronic wounds with bone marrowderived cells. Arch Dermatol. 2003;139(4):510-6. https://doi.org/10.1001/a rchderm.139.4.510.

5. Dash NR, Dash SN, Routray P, Mohapatra S, Mohapatra PC. Targeting nonhealing ulcers of lower extremity in human through autologous bone marrow-derived mesenchymal stem cells. Rejuvenation Res. 2009;12(5):35966. https://doi.org/10.1089/rej.2009.0872.

6. Rodriguez-Menocal L, Salgado M, Ford D, Van Badiavas E. Stimulation of skin and wound fibroblast migration by mesenchymal stem cells derived from normal donors and chronic wound patients. Stem Cells Transl Med. 2012; 1(3):221-9. https://doi.org/10.5966/sctm.2011-0029.

7. Shabbir A, Cox A, Rodriguez-Menocal L, Salgado M, Van Badiavas E. Mesenchymal stem cell exosomes induce proliferation and migration of normal and chronic wound fibroblasts, and enhance angiogenesis in vitro. Stem Cells Dev. 2015;24(14):1635-47. https://doi.org/10.1089/scd.2014.0316.

8. Musada GR, Dvoriantchikova G, Myer C, Ivanov D, Bhattacharya SK, Hackam AS. The effect of extrinsic Wnt/beta-catenin signaling in Muller glia on retinal ganglion cell neurite growth. Dev Neurobiol. 2020;80(3-4):98-110

9. Calhoun JD, Hawkins NA, Zachwieja NJ, Kearney JA. Cacnalg is a genetic modifier of epilepsy caused by mutation of voltage-gated sodium channel Scn2a. Epilepsia. 2016;57(6):e103-7. https://doi.org/10.1111/epi.13390.

10. Morino H, Matsuda $Y$, Muguruma K, Miyamoto R, Ohsawa R, Ohtake T, et al. A mutation in the low voltage-gated calcium channel CACNA1G alters the physiological properties of the channel, causing spinocerebellar ataxia. Mol Brain. 2015;8(1):89. https://doi.org/10.1186/s13041-015-0180-4.

11. Liu F, Gong X, Yao X, Cui L, Yin Z, Li C, et al. Variation in the CACNB2 gene is associated with functional connectivity of the hippocampus in bipolar disorder. BMC Psychiatry. 2019;19(1):62. https://doi.org/10.1186/ s12888-019-2040-8.

12. Denda S, Kumamoto J, Takei K, Tsutsumi M, Aoki H, Denda M. Ryanodine receptors are expressed in epidermal keratinocytes and associated with keratinocyte differentiation and epidermal permeability barrier homeostasis. J Invest Dermatol. 2012;132(1):69-75. https://doi.org/10.1038/jid.2011.256.

13. Nellen RG, Steijlen PM, van Steensel MA, Vreeburg M, European Professional C, Frank J, et al. Mendelian disorders of cornification caused by defects in intracellular calcium pumps: mutation update and database for variants in ATP2A2 and ATP2C1 associated with Darier disease and Hailey-Hailey disease. Hum Mutat. 2017;38(4):343-56. https://doi.org/10.1002/humu.23164

14. Blasius AL, Dubin AE, Petrus MJ, Lim BK, Narezkina A, Criado JR, et al. Hypermorphic mutation of the voltage-gated sodium channel encoding gene Scn10a causes a dramatic stimulus-dependent neurobehavioral phenotype. Proc Natl Acad Sci U S A. 2011;108(48):19413-8. https://doi. org/10.1073/pnas.1117020108.

15. Ovey IS, Naziroglu M. Homocysteine and cytosolic GSH depletion induce apoptosis and oxidative toxicity through cytosolic calcium overload in the hippocampus of aged mice: involvement of TRPM2 and TRPV1 channels. Neuroscience. 2015;284:225-33. https://doi.org/10.1016/j. neuroscience.2014.09.078

16. Saini P, Rudakou U, Yu E, Ruskey JA, Asayesh F, Laurent SB, et al. Association study of DNAJC13, UCHL1, HTRA2, GIGYF2, and EIF4G1 with Parkinson's disease. Neurobiol Aging. 2021;100:119 e7-e13.

17. Besemer AS, Maus J, Ax MDA, Stein A, Vo S, Freese C, et al. Receptormediated endocytosis 8 (RME-8)/DNAJC13 is a novel positive modulator of autophagy and stabilizes cellular protein homeostasis. Cell Mol Life Sci. 2021;78(2):645-60. https://doi.org/10.1007/s00018-020-03521-y.

18. Macken WL, Godwin A, Wheway G, Stals K, Nazlamova L, Ellard S, et al. Biallelic variants in COPB1 cause a novel, severe intellectual disability syndrome with cataracts and variable microcephaly. Genome Med. 2021; 13(1):34. https://doi.org/10.1186/s13073-021-00850-w

19. Chen H, Li K, Li Y, Xie P, He J, Zhang H. An integrative pan-cancer analysis of COPB1 based on data mining. Cancer Biomark. 2021;30(1):13-27. https:// doi.org/10.3233/CBM-200398.

20. Finsterer J. Commentary: New variant of MELAS syndrome with executive dysfunction, heteroplasmic point mutation in the MT-ND4 gene (m.
12015T>C; p.Leu419Pro) and comorbid polyglandular autoimmune syndrome type 2. Front Immunol. 2019;10:1333.

21. Chaussenot A, Rouzier C, Fragaki K, Sacconi S, Ait-El-Mkadem S, PaquisFlucklinger $\mathrm{V}$, et al. MT-CYB deletion in an encephalomyopathy with hyperintensity of middle cerebellar peduncles. Neurol Genet. 2018;4(5):e268. https://doi.org/10.1212/NXG.0000000000000268.

22. Hansen AW, Arora P, Khayat MM, Smith $L$, Lewis AM, Rossetti LZ, et al. Germline mutation in POLR2A: a heterogeneous, multi-systemic developmental disorder characterized by transcriptional dysregulation. HGG Adv. 2021;2(1):100014. https://doi.org/10.1016/j.xhgg.2020.100014. Epub 2020 Nov 20.

23. Walton SJ, Wang H, Quintero-Cadena P, Bateman A, Sternberg PW. Caenorhabditis elegans AF4/FMR2 family homolog affl-2 regulates heatshock-induced gene expression. Genetics. 2020;215(4):1039-54. https://doi. org/10.1534/genetics.120.302923.

24. Kemps PG, Cleven AHG, van Wezel T, van Eijk R, Bot FJ, Veelken H, et al. Bcell lymphoblastic lymphoma with cutaneous involvement and a KMT2A gene rearrangement. Am J Hematol. 2020;95(11):1427-9. https://doi.org/10.1 002/ajh.25801.

25. Tencer AH, Cox KL, Di L, Bridgers JB, Lyu J, Wang X, et al. Covalent modifications of histone H3K9 promote binding of CHD3. Cell Rep. 2017; 21(2):455-66. https://doi.org/10.1016/j.celrep.2017.09.054.

26. Nikkel SM, Dauber A, de Munnik S, Connolly M, Hood RL, Caluseriu O, et al. The phenotype of Floating-Harbor syndrome: clinical characterization of 52 individuals with mutations in exon 34 of SRCAP. Orphanet J Rare Dis. 2013; 8(1):63. https://doi.org/10.1186/1750-1172-8-63.

27. Mejetta S, Morey L, Pascual G, Kuebler B, Mysliwiec MR, Lee Y, et al. Jarid2 regulates mouse epidermal stem cell activation and differentiation. EMBO J. 2011;30(17):3635-46. https://doi.org/10.1038/emboj.2011.265.

28. Dalcher D, Tan JY, Bersaglieri C, Pena-Hernandez R, Vollenweider E, Zeyen S, et al. BAZ2A safeguards genome architecture of ground-state pluripotent stem cells. EMBO J. 2020;39(23):e105606. https://doi.org/10.15252/embj.202 0105606.

29. Ohta S, Taniguchi T, Sato N, Hamada M, Taniguchi H, Rappsilber J. Quantitative proteomics of the mitotic chromosome scaffold reveals the association of BAZ1B with chromosomal axes. Mol Cell Proteomics. 2019; 18(2):169-81. https://doi.org/10.1074/mcp.RA118.000923.

30. Buchsbaum S, Morris C, Bochard V, Jalinot P. Human INT6 interacts with MCM7 and regulates its stability during $S$ phase of the cell cycle. Oncogene. 2007;26(35):5132-44. https://doi.org/10.1038/sj.onc.1210314.

31. Rageul J, Park JJ, Zeng PP, Lee EA, Yang J, Hwang S, et al. SDE2 integrates into the TIMELESS-TIPIN complex to protect stalled replication forks. Nat Commun. 2020;11(1):5495. https://doi.org/10.1038/s41467-020-19162-5.

32. Lerner LK, Holzer S, Kilkenny ML, Svikovic S, Murat P, Schiavone D, et al. Timeless couples G-quadruplex detection with processing by DDX11 helicase during DNA replication. EMBO J. 2020;39(18):e104185. https://doi. org/10.15252/embj.2019104185.

33. Balmus G, Pilger D, Coates J, Demir M, Sczaniecka-Clift M, Barros AC, et al. ATM orchestrates the DNA-damage response to counter toxic nonhomologous end-joining at broken replication forks. Nat Commun. 2019; 10(1):87. https://doi.org/10.1038/s41467-018-07729-2.

34. Sowd GA, Mody D, Eggold J, Cortez D, Friedman KL, Fanning E. SV40 utilizes ATM kinase activity to prevent non-homologous end joining of broken viral DNA replication products. PLoS Pathog. 2014;10(12):e1004536. https://doi. org/10.1371/journal.ppat.1004536.

35. Shubin CB, Greider CW. The role of Rif1 in telomere length regulation is separable from its role in origin firing. Elife. 2020;9. https://doi.org/10.7554/ eLife.58066.

36. Hafner L, Lezaja A, Zhang X, Lemmens L, Shyian M, Albert B, et al. Rif1 Binding and control of chromosome-internal DNA replication origins is limited by telomere sequestration. Cell Rep. 2018;23(4):983-92. https://doi. org/10.1016/j.celrep.2018.03.113.

37. Wang J, Zhang H, Al Shibar M, Willard B, Ray A, Runge KW. Rif1 phosphorylation site analysis in telomere length regulation and the response to damaged telomeres. DNA Repair (Amst). 2018;65:26-33.

38. Wang H, Fu L, Wei D, Wang B, Zhang C, Zhu T, et al. MiR-29c-3p suppresses the migration, invasion and cell cycle in esophageal carcinoma via CCNA2/ p53 axis. Front Bioeng Biotechnol. 2020;8:75. https://doi.org/10.3389/fbioe.2 020.00075 .

39. Lee JK, Seo YS, Hurwitz J. The $\mathrm{Cdc} 23(\mathrm{Mcm} 10)$ protein is required for the phosphorylation of minichromosome maintenance complex by the Dfp1- 
Hsk1 kinase. Proc Natl Acad Sci U S A. 2003;100(5):2334-9. https://doi.org/ 0.1073/pnas.0237384100.

40. Mahmoud AD, Ballantyne MD, Miscianinov V, Pinel K, Hung J, Scanlon JP, et al. The human-specific and smooth muscle cell-enriched LncRNA SMILR promotes proliferation by regulating mitotic CENPF MRNA and drives cellcycle progression which can be targeted to limit vascular remodeling. Circ Res. 2019;125(5):535-51. https://doi.org/10.1161/CIRCRESAHA.119.314876.

41. Kouprina N, Pavlicek A, Collins NK, Nakano M, Noskov VN, Ohzeki J, et al. The microcephaly ASPM gene is expressed in proliferating tissues and encodes for a mitotic spindle protein. Hum Mol Genet. 2005;14(15):2155-65. https://doi.org/10.1093/hmg/ddi220.

42. Cook DR, Solski PA, Bultman SJ, Kauselmann G, Schoor M, Kuehn R, et al. The ect2 rho Guanine nucleotide exchange factor is essential for early mouse development and normal cell cytokinesis and migration. Genes Cancer. 2011;2(10):932-42. https://doi.org/10.1177/1947601912437035.

43. Schneider MA, Christopoulos P, Muley T, Warth A, Klingmueller U, Thomas $M$, et al. AURKA, DLGAP5, TPX2, KIF11 and CKAP5: five specific mitosisassociated genes correlate with poor prognosis for non-small cell lung cancer patients. Int J Oncol. 2017;50(2):365-72. https://doi.org/10.3892/ijo.2 017.3834 .

44. Lyu Z, Jin H, Yan Z, Hu K, Jiang H, Peng $H$, et al. Effects of NRP1 on angiogenesis and vascular maturity in endothelial cells are dependent on the expression of SEMA4D. Int J Mol Med. 2020;46(4):1321-34. https://doi. org/10.3892/ijmm.2020.4692.

45. Mei B, Chen J, Yang N, Peng Y. The regulatory mechanism and biological significance of the Snail-miR590-VEGFR-NRP1 axis in the angiogenesis, growth and metastasis of gastric cancer. Cell Death Dis. 2020;11(4):241 https://doi.org/10.1038/s41419-020-2428-x.

46. Zhu Q, Li J, Wu Q, Cheng Y, Zheng H, Zhan T, et al. Linc-OIP5 in the breast cancer cells regulates angiogenesis of human umbilical vein endothelial cells through YAP1/Notch/NRP1 signaling circuit at a tumor microenvironment. Biol Res. 2020;53(1):5. https://doi.org/10.1186/s40659-02 0-0273-0.

47. Fantin A, Herzog B, Mahmoud M, Yamaji M, Plein A, Denti L, et al. Neuropilin 1 (NRP1) hypomorphism combined with defective VEGF-A binding reveals novel roles for NRP1 in developmental and pathological angiogenesis. Development. 2014;141(3):556-62. https://doi.org/10.1242/ dev.103028.

48. Casazza A, Laoui D, Wenes M, Rizzolio S, Bassani N, Mambretti M, et al. Impeding macrophage entry into hypoxic tumor areas by Sema3A/Nrp1 signaling blockade inhibits angiogenesis and restores antitumor immunity. Cancer Cell. 2013;24(6):695-709. https://doi.org/10.1016/j.ccr.2013.11.007.

49. Fantin A, Vieira JM, Plein A, Denti L, Fruttiger M, Pollard JW, et al. NRP1 acts cell autonomously in endothelium to promote tip cell function during sprouting angiogenesis. Blood. 2013;121(12):2352-62. https://doi.org/10.11 82/blood-2012-05-424713.

50. Cui Y, Han Z, Hu Y, Song G, Hao C, Xia H, et al. MicroRNA-181b and microRNA-9 mediate arsenic-induced angiogenesis via NRP1. J Cell Physiol. 2012;227(2):772-83. https://doi.org/10.1002/jcp.22789.

51. Deb S, Felix DA, Koch P, Deb MK, Szafranski K, Buder K, et al. Tnfaip2/exoc3driven lipid metabolism is essential for stem cell differentiation and organ homeostasis. EMBO Rep. 2021;22(1):e49328. https://doi.org/10.15252/embr.2 01949328.

52. Schirwani S, McConnell V, Willoughby J, Study DDD, Balasubramanian M. Exploring the association between SRPX2 variants and neurodevelopment: how causal is it? Gene. 2019;685:50-4. https://doi. org/10.1016/j.gene.2018.10.067.

53. Yu N, Wu JL, Xiao J, Fan L, Chen SH, Li W. HIF-1alpha regulates angiogenesis via Notch1/STAT3/ETBR pathway in trophoblastic cells. Cell Cycle. 2019; 18(24):3502-12. https://doi.org/10.1080/15384101.2019.1689481.

54. Lopez-Guerra M, Xargay-Torrent S, Fuentes P, Roldan J, Gonzalez-Farre B, Rosich L, et al. Specific NOTCH1 antibody targets DLL4-induced proliferation, migration, and angiogenesis in NOTCH1-mutated $\mathrm{CLL}$ cells. Oncogene. 2020;39(6):1185-97. https://doi.org/10.1038/s41388-019-1053-6.

55. Shi S, Jin Y, Song H, Chen X. MicroRNA-34a attenuates VEGF-mediated retinal angiogenesis via targeting Notch1. Biochem Cell Biol. 2019:97(4):42330. https://doi.org/10.1139/bcb-2018-0304.

56. You C, Zhao K, Dammann P, Keyvani K, Kreitschmann-Andermahr I, Sure U, et al. EphB4 forward signalling mediates angiogenesis caused by CCM3/ PDCD10-ablation. J Cell Mol Med. 2017;21(9):1848-58. https://doi.org/1 0.1111/jcmm. 13105 .
57. Huang AH, Pan SH, Chang WH, Hong QS, Chen JJ, Yu SL. PARVA promotes metastasis by modulating ILK signalling pathway in lung adenocarcinoma. PLoS One. 2015;10(3):e0118530. https://doi.org/10.1371/journal.pone.0118530.

58. Patten J, Wang K. Fibronectin in development and wound healing. Adv Drug Deliv Rev. 2021;170:353-68.

59. Zhou HJ, Chen X, Huang Q, Liu R, Zhang H, Wang Y, et al. AIP1 mediates vascular endothelial cell growth factor receptor-3-dependent angiogenic and lymphangiogenic responses. Arterioscler Thromb Vasc Biol. 2014;34(3): 603-15. https://doi.org/10.1161/ATVBAHA.113.303053.

60. Tang H, Hao Q, Fitzgerald T, Sasaki T, Landon EJ, Inagami T. Pyk2/CAKbeta tyrosine kinase activity-mediated angiogenesis of pulmonary vascular endothelial cells. J Biol Chem. 2002;277(7):5441-7. https://doi.org/10.1074/ jbc.M110673200.

61. Chen T, Du D, Chen J, Zhou P, Weinstein JN, Yao L, et al. ZC3H12A expression in different stages of colorectal cancer. Oncoscience. 2019;6(3-4): 301-11. https://doi.org/10.18632/oncoscience.480.

62. Li A, Chan B, Felix JC, Xing Y, Li M, Brody SL, et al. Tissue-dependent consequences of Apc inactivation on proliferation and differentiation of ciliated cell progenitors via Wnt and notch signaling. PLoS One. 2013;8(4): e62215. https://doi.org/10.1371/journal.pone.0062215.

63. Yamada A, Iwata T, Yamato M, Okano T, Izumi Y. Diverse functions of secreted frizzled-related proteins in the osteoblastogenesis of human multipotent mesenchymal stromal cells. Biomaterials. 2013;34(13):3270-8. https://doi.org/10.1016/j.biomaterials.2013.01.066

64. Olsen JJ, Pohl SO, Deshmukh A, Visweswaran M, Ward NC, Arfuso F, et al. The role of Wnt signalling in angiogenesis. Clin Biochem Rev. 2017:38(3): $131-42$.

65. McBride JD, Rodriguez-Menocal L, Guzman W, Candanedo A, GarciaContreras M, Badiavas EV. Bone marrow mesenchymal stem cell-derived CD63(+) exosomes transport Wnt3a exteriorly and enhance dermal fibroblast proliferation, migration, and angiogenesis in vitro. Stem Cells Dev. 2017;26(19):1384-98. https://doi.org/10.1089/scd.2017.0087.

66. Qian L, Mahaffey JP, Alcorn HL, Anderson KV. Tissue-specific roles of Axin2 in the inhibition and activation of Wnt signaling in the mouse embryo. Proc Natl Acad Sci U S A. 2011;108(21):8692-7. https://doi.org/10.1073/pnas.11 00328108.

67. McBride JD, Rodriquez-Menocal L, Candanedo A, Guzman W, GarciaContreras M, Badiavas EV. Dual mechanism of type VII collagen transfer by bone marrow mesenchymal stem cell extracellular vesicles to recessive dystrophic epidermolysis bullosa fibroblasts. Biochimie. 2018;155:50-8. https://doi.org/10.1016/.jbiochi.2018.04.007.

68. Spuul P, Daubon T, Pitter B, Alonso F, Fremaux I, Kramer I, et al. VEGF-A/ Notch-induced podosomes proteolyse basement membrane collagen-IV during retinal sprouting angiogenesis. Cell Rep. 2016;17(2):484-500. https:// doi.org/10.1016/j.celrep.2016.09.016

69. Bignon M, Pichol-Thievend C, Hardouin J, Malbouyres M, Brechot N, Nasciutti L, et al. Lysyl oxidase-like protein-2 regulates sprouting angiogenesis and type IV collagen assembly in the endothelial basement membrane. Blood. 2011;118(14):3979-89. https://doi.org/10.1182/blood-201 0-10-313296.

\section{Publisher's Note}

Springer Nature remains neutral with regard to jurisdictional claims in published maps and institutional affiliations.

Ready to submit your research? Choose BMC and benefit from:

- fast, convenient online submission

- thorough peer review by experienced researchers in your field

- rapid publication on acceptance

- support for research data, including large and complex data types

- gold Open Access which fosters wider collaboration and increased citations

- maximum visibility for your research: over $100 \mathrm{M}$ website views per year

At BMC, research is always in progress.

Learn more biomedcentral.com/submissions 